\title{
Exploring the Problems and Challenges of Micro, Small and Medium Enterprises in Northern Province
}

\author{
Sathana Vaikunthavasan (Corresponding author) \\ Dept. of Marketing, University of Jaffna, Sri Lanka \\ E-mail: sathana1976@gmail.com or vsathana@univ.jfn.ac.lk
}

Prof. T. Velnampy

Dean, Faculty of Management Studies and Commerce,

University of Jaffna, Sri Lanka

E-mail: tvnampy@yahoo.co.in

Dr. S. Rajumesh

Dept. of Marketing, University of Jaffna, Sri Lanka

E-mail: rajumesh3@yahoo.com

Received: Feb. 3, 2019 Accepted: Feb. 28, 2019 Published: April 19, 2019

doi:10.5296/bmh.v7i1.14314 URL: http://dx.doi.org/10.5296/bmh.v7i1.14314

\begin{abstract}
The purpose of this study is to identify the problems and challenges of SMEs in the postwar situation of Northern Province. Researcher conducted qualitative exploratory research; explain the phenomenon of problematic situation of SMEs in Northern Province. By applying purposive sampling technique, with primary data collection method of focus group discussion and interviews were conducted with the owners of SMEs and officers related with the SMEs in the Northern Province. Finding of the study explains, first, marketing problems which includes product problems, pricing problems, promotion problem, distribution based problems, green problem and network problems, second, internal problem which includes financial problems and employee problems third, characteristics of entrepreneurs as problems, at last external problems, namely political and legal, economic and socio economic problems.
\end{abstract}




\section{Macrothink}

The important implication is that this study indicates clearly the problems and challenges of SMEs in the post war market. It will help the owners of SMEs the means to solve these problems, and govern officers to understand the means to support the SMEs.

Keywords: problems and challenges, Micro, Small and Medium Enterprises (SMEs), post war market 


\section{Introduction}

Micro, Small and Medium Enterprises (SMEs) are the prime business sectors in Sri Lanka. The Government of Sri Lanka recognizes SMEs as the backbone of the economy, as it accounts for more than $75 \%$ of the total number of enterprises, provides $45 \%$ of the employment and contributes to $52 \%$ of the Gross Domestic Production (GDP) (National policy Framework for SME Development, 2015). SMEs promote broad based equitable development and provide more opportunity for women and youth participation in the economic development of the country. SMEs are an essential source for employment opportunity. SME sector of Sri Lanka has not achieved desired level of contribution when compared with other developed and developing countries (Gamage, 2003). Vijayakumar (2013) expressed that SMEs have a less performance as against the larger scale business in Sri Lanka. Gajanayake (2010) revealed a high failure rate of SMEs in Sri Lanka based on the past studies. In 1983, 98\% of small enterprises account for $48.6 \%$ of total employment and $31.1 \%$ of value added ( Vijayakumar, 2013). In 2008, 91.6\% of small enterprises account for $29.6 \%$ total employment and $20.3 \%$ of value added (Department of Census and Statistics, 2013/14; Vijayakumar, 2013). This data shows the decreasing trends of SMEs in Sri Lanka. Local war created huge unbelievable marks for Northern Province. After the war huge displacement of people, damaged infrastructure, poor education and in-security prepared very low GDP contribution from Northern Province. SMEs in Northern Province have been recovering from the war wounds. There are many efforts to reconstruct and rehabilitate the school, banks, roads, power and energy and other key infrastructure in Northern Province. SMEs can be in progress with low investments and more labor per unit of capital employed implying and promoting this sector offers huge employment opportunities. There are very few mass industries and many SMEs in Northern Province. In the Northern Province (NP) $99 \%$ of business are under the SMEs sector (Department of census and statistic, 2013/14), the contribution of GDP of NP is only $3.4 \%$ in $2010,3.7 \%$ in $2011,3.3 \%$ in $2014,3.5 \%$ in 2015 (CBSL, 2016), this is very lower level compared with the contribution of other Provinces. There is rapid resettlement for displaced people in Northern Province. Infrastructure and other services have been provided to pick up life and move on. Even though rapid resettlement was focused and conducted, rural areas in Northern Province are still struggling with basic infrastructure and all other essential facilities. The growth and expansion of SMEs in Northern Province are constrained by problems emanating from product and factor markets and the regulatory system they operate in. Furthermore many challenges have been faced to develop the SMEs in Northern Province. The poor attitudes of entrepreneurs and less innovative means of the SMEs are backlog in its improvement (Baker, 2003). No any other clear ideas about the problems and challenges are for SMEs in the post war market . It is clear that SMEs in the post war market have been suffering from huge problems and challenges, at the same time SMEs have been poorly performing. No one identified the problems and challenges of SMEs in the post war market. So it is essential to research on identifying problems and challenges to improve and develop SMEs in the post war market, Northern Province. This research tries to identify the problems and challenges from prevailing post war environment which are sustained by the SMEs in Northern Province. 


\section{Research Gap and Problem Statement}

Kapurubandara \& Lawson (2006) presented a model for barriers to adoption of Information Communication Technology (ICT) and e-commerce for SMEs in Sri Lanka, collected from the available literature and the results of an exploratory pilot studies and subsequent survey. In addition to the barriers facing SMEs, this research identified the relevant support required by SMEs in a developing country, Sri Lanka. Priyanath \& Premaratne (2014) analyzed the activities of each SME development program being currently implemented by the Sri Lankan government, employing qualitative content analysis to understand whether they facilitate to access information and to select appropriate governance mechanism. Business Development Centre (SLBDC) carried out a research study in 2002 on the opportunities and challenges faced by the Sri Lankan Small and Medium Size Enterprises (SMEs) in adapting e -commerce into their daily business routines. Nishantha \& Padmasiri (2010) examined the current role of SMEs in different industries, as well as understanding their contribution to the economy and identify the possibilities for promoting SMEs in the Sri Lanka. Kirushanthy (2015) carried out to understand the main causes of the business failure of SMEs in Baticaloa district. Shivani and Thirunavukkarasu (2015) conducted research to identify the challenges of post war marketer in Northern Province. Very few researchers involved in conducting research regarding SMEs covering all part of the country (Ayyagari, Beck, and Demirguc-Kunt, 2007; Gajanayake, 2010). But problems and challenges are not studied for SMEs in Sri Lanka. Many researchers have been diagnosing and evaluating the problematic situation and challenges in different industries (Bang \& Joshi, 2010; Bang, Joshi \& Singh, 2015), but no one researched on the problems and challenges of SMEs in the post war Northern Province. Hence it is very important to study the problematic and challenging factors for SMEs developments in Northern Province. So there is need to identify the major problems and challenges for SMEs in Northern Province with the qualitative perspective. This research try to identify "What are problems and challenges of SMEs in Northern Province"?

\section{Literature Review}

\subsection{Small and Medium Enterprises (SMES)}

There is no standard definition of small and medium enterprise in international practices and definition vary across countries and also across different organizations within a country. The term SME is used to denote micro, small and medium enterprises. Different countries use different definitions for SMEs, based on their level of development. SMEs are defined in a variety of ways by various countries usingdifferent parameters such as number of persons employed, amount of capital invested, amount of turnover or nature of the business, etc. 
Table 1. Defining SMEs in Sri Lanka

\begin{tabular}{lllll}
\hline $\begin{array}{l}\text { Sector } \\
\text { Manufacturing } \\
\text { Sector }\end{array}$ & $\begin{array}{l}\text { Criteria } \\
\text { Annual Turnover }\end{array}$ & $\begin{array}{l}\text { Medium } \\
\text { Rs. Mn. 251-750 }\end{array}$ & $\begin{array}{l}\text { Small } \\
\text { Rs. Mn.16-250 }\end{array}$ & $\begin{array}{l}\text { Micro } \\
\text { Less than Rs. Mn. } \\
15\end{array}$ \\
& No. of Employees & $51-300$ & $11-50$ & $\begin{array}{l}\text { Less than } 10 \\
\text { Service Sector }\end{array}$ \\
& Annual Turnover & Rs. Mn. 251-750 & Rs. Mn.16-250 & $\begin{array}{l}\text { Less than Rs. Mn. } \\
15\end{array}$ \\
& No. of Employees & $51-200$ & $11-50$ & Less than 10 \\
\hline
\end{tabular}

Source: National Policy Framework for SME Development, 2015.

According to the recent guidelines issued by the Central Bank of Sri Lanka, SME is defined as enterprises that have an annual turnover less than Rs 600 million and its borrowings below Rs 200 million (CBSL, 2016). The Sri Lanka Export Development Board (SLEDB) for export oriented enterprises, SMEs are defined as those enterprises with a capital investment excluding land and buildings of less than Rs 8 million or with annual export turnover of less than Rs 50 million (Gamage,2003). In the Sri Lankan context, the SME policy framework defines SMEs based on the number of employees and annual turnover, it is displayed by the table 1. The category of Small and Medium sized Enterprises (SMEs) is made up of a enterprises which employ less than 300 employees and which have an annual turnover not exceeding Rs.750 Mn (Table 1).

Listing data collected at the economic Census exhibites that the number of persons engaged to be the most reliable and consistent variable in defining SMEs. Viyajakumar (2013) demonstrated that generally, the number of employees as a criterion could be more acceptable because other criteria can be affected by inflation. Consequently, the thresholds identified to define micro, small, medium and large scale establishments for each of the major economic sectors are as follows:

Table 2. Defining SMEs

\begin{tabular}{lll}
\hline Major economic sector & SME Groups & Criteria (Number of Persons Engaged) \\
\hline Industry and Construction & Micro & 1 to 4 \\
& Small & 5 to 24 \\
& Medium & 25 to 199 \\
Large & 200 and above \\
& Micro & 1 to 3 \\
& Small & 4 to 14 \\
& Medium & 15 to 34 \\
Services & Large & 35 and above \\
& Micro & 1 to 4 \\
& Small & 5 to 15 \\
& Medium & 16 to 74 \\
& Large & 75 and above \\
\hline
\end{tabular}

Source: Department of Census and Statistics, 2013/2014 


\subsection{Problems and Challenges for Development of SMEs}

The challenges for the development of SMEs are financial capital, infrastructure, employment opportunity, greater utilization of machinery, equipment and raw materials and intellectual and skill employees, sub-contracting with formal and informal sectors (Gamage, 2003). In the external context, environmental regulation, government incentives for innovation and environmental actions, environmental protection, supply chain impacts their environmental strategic decisions and technological competence are also considered as challenges. They must be managed jointly and interactively between the barriers and drivers in the adoption of environmentally friendly practices and technologies. Internal factors that lead to eco-innovation management were also analyzed. In general, the support of the company's senior management, which becomes crucial for decision making in this field, the skills and capabilities of technological absorption of companies, which provide the necessary conditions for this adoption, the more its culture and features are so modified, with the internalization of environmental preservation. Furthermore, certain intervening variables were also considered, which may affect the organizations, such as the organization's size, age, origin of capital and market of operation (Maçaneiro \& da Cunha, 2014). The main problems that small and medium enterprises encounter, especially during the start-up phase, deal with the lack of financial resources and also with administrative barriers in terms of bureaucracy (Kapurubandara \& Lawson, 2006). The SMEs in developing countries fall behind with adoption due to barriers, both internal and external, prominent and inherent in a developing country as cultural, infrastructure, political, social, and legal and regulatory Barriers. Interpretation of preliminary internal barriers: such as the lack of skills required and the lack of awareness of any return on investment (Kapurubandara \& Lawson, 2006)

\section{Methodology}

Researcher applied qualitative methodology in this research. Qualitative research was concerned with developing explanations of social phenomena in this study. Researcher conducted exploratory research and used exploration of the existing certain phenomena. It analyzes the practices of existing and ideas to the future. This study was conducted in Northern Province in Sri Lanka. The unit of analysis in this study is owners of SME in the Northern Province. This research followed the purposive sampling method. The sampling units may be individuals or they may be in groups. Each member of sampling frame is called sampling unit. Each owners of SMEs and government officers related with SMEs were sampling units in this research. Sample contained 2 focus group discussion (dairy farm entrepreneurs and coconut based entrepreneurs) 10 officers (Divisional secretariat-3, Regional manager central bank-1, department of industries-1, industrial development board-2, UBL-1, Jaffna college of technology -1 and directors of coconut cultivation board-1) and 49 owners of SMEs in Northern Province. Primary data collection method was applied in this research. Data collection instrument was the focus group discussion and interview method. Researcher utilized the ideas of previous research to develop the questions (Gamage, 2003; Perera \& Wijesinha, 2011). Further secondary data was gathered from Journals, articles in newspapers, books, SMEs publication and reports, central bank reports and publications, and government organizations' data banks and publications. 


\section{Macrothink}

\section{Data Analysis}

\subsection{Descriptive Statistics}

Data survey was conducted with the 49 subjects (SMEs). The profile of samples were explained by the table 3 .

Table 3. Demographic profile of samples

\begin{tabular}{lll}
\hline SMEs & Number of respondent & Respondent in \% \\
\hline Type & & \\
Manufacturing & 36 & $73 \%$ \\
Service & 13 & $27 \%$ \\
Districts & & \\
Jaffna & 17 & $35 \%$ \\
Killinochchi & 13 & $26 \%$ \\
Mullaitivu & 07 & $14 \%$ \\
Mannar & 12 & $25 \%$ \\
\hline
\end{tabular}

Researcher had focus group discussion; "Are you facing any problems to conduct your organization success fully"? The Answer from dairy farm producers is:

"Yes, we are facing different kinds of problems, we are getting low price for our milk, curd and gee from intermediaries, but they sell our product with higher prices. We haven't adequate equipment facilities to store and packge our product, we didn't register our business, and registration of business requires many procedure....

Another answer for coconut based producers:

"yes, our problems are: inadequate coconut husk, no proper infrastructure facilities to process high quality raw material as no salt water and no proper place to dig the coconut husk, no idea about the market opportunity of product, only we prepare and try to sell our product, no innovative product, we use only basic machineries, huge dust come out during the process and risk to manually handle the machine, no any mask and safety equipment...",

Researcher interviewed officer from department of industry, first question "Are you dealing with SMEs, in which way? Do you feel that SMEs facing any problems to be success and survive in the environment?

"Yes, we provide trainings, market opportunity by trade exhibition, link SMEs with supplier and intermediaries....... Yes SMEs are facing huge problems. Micro firm produces low quality product compared with national and international brands, most of the micro producers did not register their business, they can't full fill for the requirement of registration, so they unable to use their brand name , 
Researcher utilized NVivo software of QRS international. Interview was conducted using audio recording, then it was translated and transcribed. Initially the themes were pointed as observed or recorded. Then open code and axial coding were applied to code the data. The open coding is the researcher identification and then second order coding by using in -vivo called as first order coding. Then the axial coding was revealed the themes of second - order from first coding categories. The second order themes were revealed as emergent framework base on Corley and Gioia (2004). Appendix A displays in-vivo codes and first order, second order and findings respectively in the annexure.

\subsection{Reliability and Validity}

Researcher utilized NVivo (version 11) to extract subjects' records, transcript and other related document. The validity of this research was presented as five (Silverman and Marvasti, 2008). First the respondent validation, researcher shared the findings with the study subjects and discuss opinion of them regarding the interpretation and credibility of findings. Second refutability was disproved by having diverse subjects to collect the data. Third constant comparison was made by displaying the additional research and expanded data collection to validate emergent findings. Forth under the comprehensive data treatment, researcher examined the data again and again to draw the comprehensive suggestions and conclusions. The fifth deviant-case all interviews were recorded and translated properly without any deviant cases by using Nvivo software to manage the data and findings properly.

\section{Findings}

In discussing the questions, subjects have given most valuable information regarding the problem of the SMEs. According to the coding method, identified problems are: marketing problems, internal problems, external problems and entrepreneurs' characteristics.

\subsection{Marketing Problems}

Marketing problems include product based problems, price based problems, promotion based problems, distribution based, green problems and network relationship problems.

Product based problems: SMEs have limited resources, they have adopted traditional based and mostly manual productions with very few innovated technological equipment. Further SMEs have not applied any innovative or creative production methods. In addition, most of the SMEs are micro enterprises, they haven't any research and development on customers, product advancement and product innovations. SMEs have rare differentiation in designs and models and lack of product enhancements. Most of the Micro entrepreneurs do not register their business. They didn't use brand name. Products of SMEs haven't high quality, poor finishing poor packaging and insufficient information on the packaging regarding products. There are high requirements to get quality standards a GMP (Goods manufacturing process), SLS (Sri Lanka Standard) or ISO (International standard organization). Further it is hard to get the approval of patent and copyright, that is, huge procedure and none of offices in Northern Province. There are potential number of women headed families involving in the SME business in the postwar market. But there is limited mobility access of raw material for women entrepreneurs. 
Pricing problems: There is no separate policies regarding tax system for the war affected places, high tax rate badly effects on the prices of SME product or services. Further SMEs haven't sufficiently maintain any accounting system, don't know about pricing calculation, they only consider competitors prices and finalize the prices. The inflation in Sri Lanka leads to high cost of labor, raw material and other cost of production. Due to this SMEs impose low margin and have high price, consequently decrease in demands for products. Floating exchange rate leads risk in foreign export income of SMEs.

Promotion problems: SMEs have been using few media to disseminate information, because of high cost of advertising and promotion and poor support of media to convey the message about product or services of SMEs. So there is low awareness about the product or services of SMEs. Further most of the SMEs are technology back in disseminating information, they fail to create web site and use social networking.

Distribution problems: SMEs have few distribution channels and business linkage, low demand, low sales, low number of customers and high customer turnover. Further all SMEs have been facing huge competition from national and international brands. SMEs poorly use e-marketing. Most of the women entrepreneurs are able to access only limited market for their products.

Environmental (green) problem: SMEs are requested to fulfill some requirements to register their business. Important requirement is environmental certification regarding air, emission, noise and vibration, waste water and solid waste. Further government imposes high restrictions to balance and care environment and consider on natural resources such as sea food quota system to fishery industry and raw material exploitation. Food based industries must be certified under stringent food safety. Further SMEs sustain high energy cost and poor environmental management in their business.

Poor network relationship: entrepreneurs poorly interact with customers and fail to identify the needs and want of customers. Entrepreneur are unknown about the facilities, and services of various organizations and poorly collaborated with the stakeholders of SMEs such as universities and other education institutions, research institutes, media institutions to access innovative technology facilities, consultancy and other services.

\subsection{Internal Problems}

Internal problems are listed as financial and labor problems.

Financial problems: SMEs suffer from low sales, turn over and profits. Further they suffer by inadequate fund for investment and growth of SMEs.

Employee problems: there is few application of technological and innovated equipment for SMEs products, so they depend on manual based production. Employees are expected to work more and they get stress, dissatisfaction on work, high absenteeism, and labor turnover. Further SEMs do not adopted poor working environment as poor occupational safety and health facilities. 


\subsection{External Problems}

External problems are listed under the three categories as political and legal, socio culture and economic problems.

Political and legal problems are: Government has been changing the policies over the time regarding SMEs. Entrepreneurs have not been informed the properly these changing policies. Compensation policies have not adopted to displaced entrepreneur to restart or recover from post war situation. The policies regarding the educational and professional qualifications for SME business are not defined well. Further defined SMEs' policies are not implemented properly. Laws regarding EPF and ETF and child labor law creates huge barrier for poor people to work with SMEs. The huge area of usable land is in the hand of government after the local war.

Economic problems: central bank introduced favorable loan scheme with low interest rate for SMEs, but in practice, banks need many documentary and guarantee requirements. SMEs feel that high tax rate is imposed on their product and services.

Socio cultures problems: there is very rare participation of women in SME business. Even they participated, males are dominated and women are assisting to them.

\subsection{Characteristics of Entrepreneurs}

Entrepreneurs have poor financial literacy regarding loan utilizations and loan repayment. They earn limited income and sustain restricted life style. They possess inadequate education, professional qualification and IT knowledge. Media awareness, web, internet, networking knowledge is very poor to SME employees. Most of the entrepreneurs have negative attitude regarding their growth and development, they are risk avoiders and not future perspective thinking and they possess easy earning expectation.

\section{Conclusion and Discussion}

SEMs are back bone of all nations. Secondary data shows that SMEs has been facing huge problems by the indicators of total employment and value added in Sri Lanka (Vijayakumar, 2013). Shivani and Thirunavukkarasu (2015) mentioned that all marketers in the post war have been facing severe problems. SME sector cover $99 \%$ of business in Northern Province. Northern Province contributes to GDP by below 5\% over the ten years. This situation explains the problematic situation of SMEs. Researcher identified problems with owners of SMEs and government and non-government officers related with the SMEs. By using interview and focus group discussion, problems were derived, then it was coded with NVivo software.

Finding shows that all micro, small and medium entrepreneurs are facing problems, but based on the business type the problem vary and small entrepreneurs are also facing huge problems. SMEs have been facing significant marketing problems under the category of product, price, promotion and distribution related, then network relationship related and green environmental related problems. Further SMEs suffer from financial and employee related problems. In addition external problems namely, political, legal, economic and socio cultural problems 
also effect on the SMEs.

Under the problems, marketing problems are discovered as major problems in this research. Baker (2003) SMEs focus on a segment and can have innovative production or services for that segment. This research also explains that huge marketing problems are highlighted with innovative product, promotions and distribution problems. O'Dwyer, Gilmore and Carson, (2009) stressed to apply innovating marketing for SMEs, it covered not just relate to products, new product development, and technological development but is also evident in other aspects of marketing related activities of the SME. The marketing capability, which are regarding the ability of the company to develop a range of aspects related to the marketing of products, including: distribution and promotion network, are highly expected to success of SMEs (Sulistyo, 2016). These capabilities are essential determinant of innovative marketing. These capabilities are in problems for SMEs in Northern Province.

There is a lengthy gap among policy makers, implementers, service providers and owners of SMEs. There must be a smooth relationship among stakeholder, it gives more benefit for organization (Gummesson, 1994). Relationship marketing is now viewed as network marketing for SME context (Lin and Lin, 2016; Baker 2003). SMEs in Northern Province are very lack of practices of network relationships. Government produces policies, tax system and laws are composed commonly for all organizations and without consideration and interaction with SMEs. Lack of network relationship is major barriers for SME growth and development. Government and non- government institutions are providing the services for the SMEs in Sri Lanka. The basic services are registration of business, issuing environmental certificates and quality standard certificate and PHI (Protected Health Information) certificates and EPF \& ETF services. Development and supportive services are awareness workshops and programs regarding labor rules and regulations, environmental regulations or greener product, quality standard products, new machinery and instrument purchase, technology transfer and value added to product. Further it includes export advices, financial literacy regarding loans, technology adaptation knowledge, budget and business planning, technical upgrading plan, ideas of technical expert regarding Material, machinery, technology, and product upgrading, structure and layout creation ideas and sustainable market ideas. They encourage to upgrade micro entrepreneur to small, small to medium, women and student participation in entrepreneurship. Assistances which are offered for SMEs are market opportunities, e-commerce training and facilities, export link, professional training, field visit, research assistances, attitude blast counselling, forums regarding financial, marketing and management development, fund assistances, business link-for supplier, producer and distributor and local, national, and international exhibition. Due to lack of network application, SMEs fail to identify and utilize these service properly.

Micro enterprises produce green and natural products by using natural raw materials, manual based or traditional based productions. Increasing green concern and consumption create more opportunity for SMEs (Chahal, Dangwal, and Raina, 2014). But other applications of green marketing such as green packaging, green process, green supply chain and green waste disposal were in the major environmental problems for SMEs in the post war market. 


\section{Implication}

Present study clearly identified major problems of SMEs in the post war Northern Province. SMEs possess limited financial resources and employees resources, lack of managerial resources and functional specialist, few management decision makers, they are not to have specialist experts, generalists, lack of marketing expertise and mostly individualistic decision making in all problematic situation (Stubblefield Loucks, Martens and Cho, 2010; Baker 2003). This research helps owners of SMEs to identify the problems root and which problems wants to take more to solve and then they can have effective decision marketing. This research listed marketing problem as major one for SMEs. Innovative marketing is huge dominant factor on success of SMEs, but this research revealed innovation on all marketing mix variables is in problematic in SMEs in the post war market. Entrepreneurs want to take more attention on the innovative marketing activities, which leads to growth and development of organization. Further these identified problems clearly indicate that there is a vital gap among SMEs and stakeholder. This research stressed that the network among SMEs and stakeholder is essential for the success of SMEs.

\section{References}

Ayyagari, M., Beck, T., \& Demirguc-Kunt, A., (2007). Small and Medium Enterprises Across the Globe. Small Business Economics. Retrieved from https://elibrary.worldbank.org/doi/abs/10.1596/1813-9450-3127

Baker, M. (2003). The marketing book. Routledge.

Bang, V. V., \& Joshi, S. L. (2010). Market expansion strategy-performance relationship. Journal of Strategic Marketing, 18(1), 57-75. https://doi.org/10.1080/09652540903511316

Bang, V. V., Joshi, S. L., \& Singh, M. C. (2015). Marketing strategy in emerging markets: a conceptual framework. Journal of Strategic Marketing, 1-14. https://doi.org/10.1080/0965254X.2015.1011200

CBSL. (2016). Press release of Statistics Department.

Chahal, H., Dangwal, R., \& Raina, S. (2014). Conceptualization, development and validation of green marketing orientation (GMO) of SMEs in India: a case of electric sector. Journal of Global Responsibility, 5(2), 312-337. https://doi.org/10.1108/JGR-02-2014-0005

Corley, K. G., \& Gioia, D. A. (2004). Identify ambiguity and change in the wake of a corporate Spin-off. Administrative Science Quarterly, 29, 173-208. https://doi.org/10.2307/4131471

Department of census and statistic. (2013/14). Atlas of Economic Activities of Sri Lanka, Ministry of National Policies and Economic affairs. Retrieved from http.www.satistics.gov.lk

ESBA (2011). Micro and small Business in the EU, European Small Business Alliance. Retrieved form http://www.esba-europe.org/

Gajanayake, R. (2010). The Impact of Marketing Strategies and Behavior of Small and 
Medium Enterprises on their Business Growth.

Gamage, A. S. (2003). Small and Medium Enterprise Development in Sri Lanka: A Review. Meijo University, Faculty of Business Management, Nagoya, Japan.

Gummesson, E. (1994). Making relationship marketing operational. International Journal of service industry management, 5(5), 5-20.

Kapurubandara, M., \& Lawson, R. (2006). Barriers to Adopting ICT and e-commerce with SMEs in Developing Countries: An Exploratory study in Sri Lanka, School of Computing and Mathematics, University of Western Sydney, Australia

Lin, F. J., \& Lin, Y. H. (2016). The effect of network relationship on the performance of SMEs. Journal of Business Research, 69(5), 1780-1784.

Kirushanathy, K. (2015) Factors contributing to the failure of the Small, Medium scale Enterprises: A survey based study in Manmunai North Divisional Secretariat DivisionBatticaloa District, Proceeding of International Conference on contemporary Management, (ICCM) pp. 471-486.

Maçaneiro, M. B., \& da Cunha, S. K. (2014). Theoretical Analysis Model of the Adoption of Reactive and Proactive Eco-Innovation Strategies: the Influence of Contextual Factors Internal and External to Organizations. BBR-Brazilian Business Review, 11(5), 1-23. https://doi.org/10.15728/bbr.2014.11.5.1

National policy Framework for Small Medium Enterprise (SME) Development. (2015). Ministry of Industry and commerce.

Nishantha, B., \& Padmasiri, H. N. (2010). Development of Small and Medium Enterprises in Post Conflict Sri Lanka: Opportunities, Challenges and Policy Implications.

O'Dwyer, M., Gilmore, A., \& Carson, D. (2009). Innovative marketing in SMEs. European Journal of Marketing, 43(1/2), 46-61. https://doi.org/10.1108/03090560910923238

Perera, D., \& Wijesinha, A. (2011). SME Development Strategies for Sri Lanka: Learning Lessons from Neighboring Countries.

Priyanath, H. M. S., \& Premaratne, S. P. (2014). Government SME Development Programs in Sri Lanka: A Review in the Lens of Transaction Cost Economics. Sabaragamuwa University Journal, 13(2), 59-81.

Rust, R. T., \& Cooil, B. (1994). Reliability measures for qualitative data: Theory and implications. Journal of Marketing Research, 1-14. https://doi.org/10.1177/002224379403100101

Shivany, S., \& Thirunavukkarasu, V. (2015). Grounded Theory as a Methodology for Exploring Marketing Strategies for a Special Context.

Silverman, D., \& Marvasti, A. (2008). Doing qualitative research: a comprehensive research: a comprehensive guide. Thousand Oaks, CA: Sage. 


\section{Macrothink}

Business and Management Horizons

ISSN 2326-0297

2019, Vol. 7, No. 1

SME: Back born of the Economy. (2003). The Sunday times, business times.

Stubblefield Loucks, E., Martens, M. L., \& Cho, C. H. (2010). Engaging small-and medium-sized businesses in sustainability. Sustainability Accounting, Management and Policy Journal, 1(2), 178-200. https://doi.org/10.1108/20408021011089239

Sulistyo, H. (2016). Innovation capability of SMEs through entrepreneurship, marketing capability, relational capital and empowerment. Asia Pacific Management Review, 21(4), 196-203. https://doi.org/10.1016/j.apmrv.2016.02.002

Tang, Z., \& Hull, C. E. (2011). The strategy configuration of Chinese SMEs. Journal of Enterprising Culture, 19(03), 229-259. https://doi.org/10.1142/S0218495811000799

Vijayakumar, S. (2012). Growth and issues of small and medium enterprises in post conflict Jaffna Sri Lanka. Economia Seria Management, 16(1), 38-53.

\section{Appendix A}

In-Vivo Codes, First-Order Categories and Second Order Themes

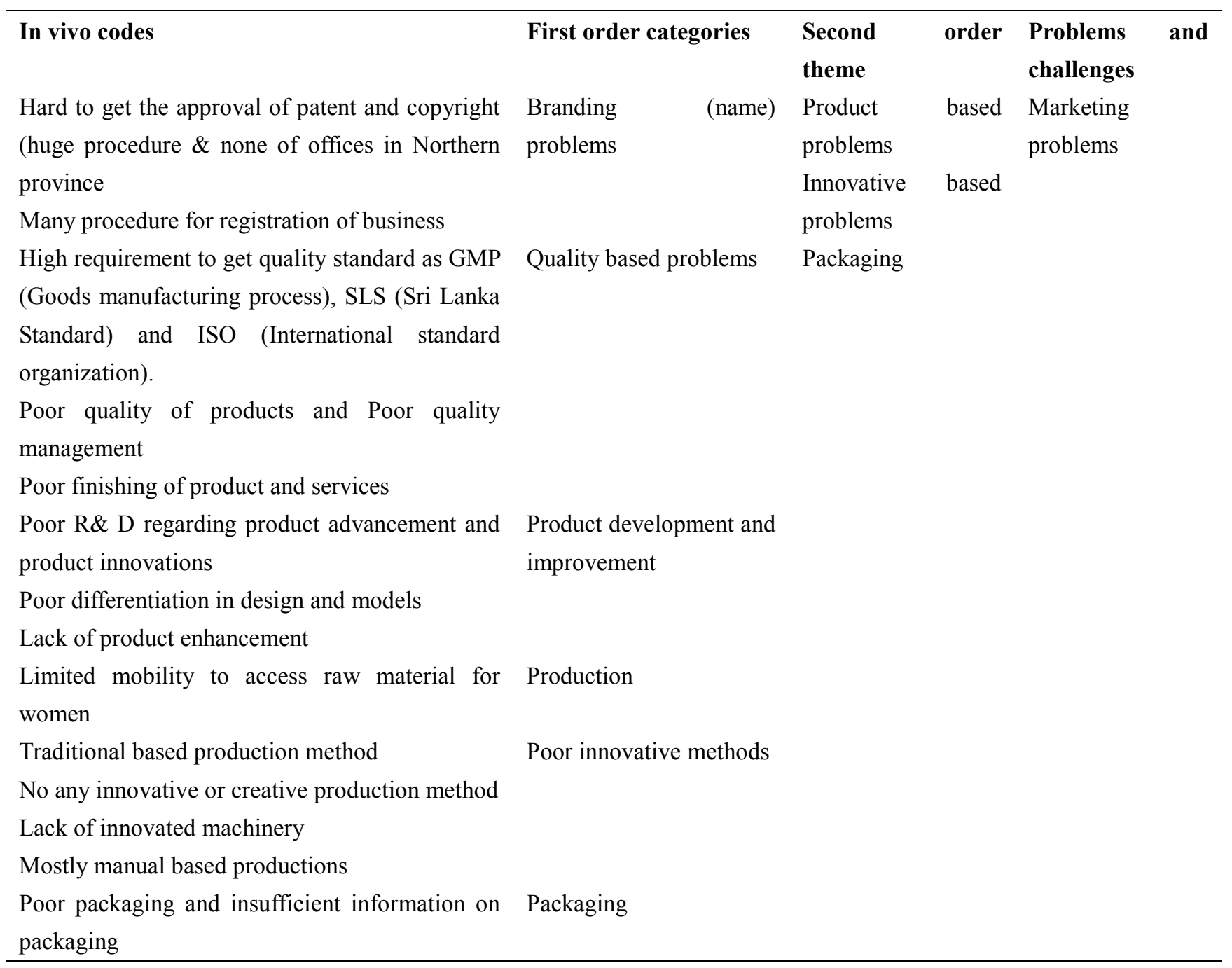


Increasing inflation leads to high labor cost, raw material and other cost

High cost of production, low margin, increase in price and decrease in demands for products.

No separate policies regarding tax system to war affected places

Floating exchange rate leads risk in foreign export income

No accounting system for cost or sales price calculations

Lack of advertising/ Poor media support to convey the proper message to SMEs

Technology back in disseminating information

Lack of social network marketing system

Poor media support to convey the proper message to SMEs

Poor awareness about product to customers

High cost of advertising and promotions

Low demand, low sales, low number of customers, high customer turn over

Few distributions

High competition from national and international brand

Poor web based e- marketing,

Limited market access for women entrepreneurs

High requirement for environmental certification regarding air, emission, noise and vibration, waste water and solid waste

High environmental care and consideration eg: Sea food quota system to fishery industry, High restrictions because of environment balance and raw material exploitation

Certified under stringent food safety

Poor environmental management

High energy cost

Entrepreneur are unknown about the facilities and services of various organizations,
High Production cost and Pricing problems

low demand

High tax

Effect on pricing system

Poor Price calculating system

Poor promotions

Promotion problems

Poor technological

application in

promotions

Inadequate media

support

Poor customer reach

High cost of Promotions

Low

customer

satisfaction

Distribution

Inadequate distributions

High competitions

Poor innovative sale applications

Environmental

Environmental(gree

requirements

n) problems
High Environmental considerations

$\begin{array}{ll}\text { Poor relationship } & \text { Poor network } \\ \text { Poor network } & \text { relationship }\end{array}$


poor collaboration and relationship with the stakeholders of SMES such as universities, R\& $\mathrm{D}$, media, innovative technology facilities and consultancy

Lack of research about the needs and want of customers

Government changing the policies over the time regarding SMEs

Entrepreneurs have not been informed the changing policies

The huge area of usable land is in the hand of government after the local war

Labor low barriers regarding EPF and ETF

undefined wag level for employees

child labor law restriction

The Policies regarding the educational and professional qualifications for SME business are not defined well poor SME policy implementation,

Poor compensation policies to displaced entrepreneur to restart or recover from post war situation,

Poor compensation to displaced entrepreneur to restart or recover from post war situation
Government policies

Political and legal

External problems
Legal problems

Poor Government

contribution to SMEs

\section{Copyright Disclaimer}

Copyright for this article is retained by the author(s), with first publication rights granted to the journal.

This is an open-access article distributed under the terms and conditions of the Creative Commons Attribution license (http://creativecommons.org/licenses/by/3.0/). 